Indo. J. Chem. Res., 2019, 6(2), 88-93

\title{
ANALISIS KANDUNGAN ZAT BESI (Fe) PADA DAUN KELOR (Moringa oleifera Lam) YANG TUMBUH DENGAN KETINGGIAN BERBEDA DI DAERAH KOTA BAUBAU
}

\author{
Analysis of Ferrum Content (Fe) in The Kelor Leaves \\ (Moringa oleifera Lam) With The Height Growing Areas In Baubau
}

\author{
Hasty Hamzah*, Nur Rahmah Yusuf \\ Study Program of Pharmacy, Politeknik Baubau \\ Jalan. Lakarambau Kota Baubau 93721 \\ *Corresponding author, e-mail: hastyhamzah@gmail.com
}

Received: Dec. 2018 Published: Jan. 2019

\begin{abstract}
Moringa oleifera Lam. is ones of the multipurpose plants. All parts of the plants are useful to human life and efficacious as a medicine. Moringa oleifera Lam can grow in the lowlands and highlands to an altitude of 1000 masl. This study was conducted to determine the levels of iron (Fe) in Moringa oleifera Lam leaves that grew at different heights using Atomic Absorption Spectroscopy (AAS) the results shows the amount of iron (Fe) in the lowlands of 14 masl (Wameo Village) is $6.28 \mathrm{mg}$ per $100 \mathrm{~g}$ of Moringa leaf, medium plains 58 masl (Kantalai Village) is $5.57 \mathrm{mg}$ per $100 \mathrm{~g}$ of sample while in the highlands 318 masl (Kaisabu Subdistrict) is $3.86 \mathrm{mg}$ per $100 \mathrm{~g}$ of sample. Factors that influence the amount of iron content in Moringa oleifera Lam leaves are height which further affects the intensity of sunlight, humidity. Other factors can be caused by soil conditions (texture, moisture, nutrient, and $\mathrm{pH}$ ).
\end{abstract}

Keywords: Moringa leaves, herbal, growing height, ferrum, Atomic Absorption Spectroscop(AAS)

\section{PENDAHULUAN}

Salah satu bahan makanan yang mengandung zat besi tinggi adalah tanaman kelor. Tanaman kelor (Moringa oleifera Lam.) atau yang dikenal dengan nama kaudawa untuk daerah Baubau dalam bahasa Wolio. Kelor, merupakan tanaman perdu dengan tinggi sampai 10 meter, berbatang lunak dan rapuh, dengan daun sebesar ujung jari berbentuk bulat telur dan tersusun majemuk. Dari segi anatomi suku Moringa ini mempunyai sifat yang khas yaitu terdapatnya sel-sel mirosin dan buluh-buluh gom dalam kulit batang dan cabang. Selain dari itu, dalam musim-musim tertentu dapat menggugurkan daun-daunnya (meranggas) (Tjitrosoepomo, 2013). Daunnya berwarna hijau menyirip ganda dengan anak daun menyirip ganjil dan helaian daunnya bulat telur, bunga kelor merupakan malai yang keluar dari ketiak daun, sedangkan buahnya menggantung sepanjang 20-45 cm dan isinya sederetan biji bulat bersayap tiga (Winarti, 2010). Di Indonesia kelor menyebar mulai dari Jawa, Sumatra, Kalimantan, Sulawesi, NTB, NTT dan lainnya.
Adapun nama lainnya di Sulawesi disebut Kero, wori, kelo atau keloro (Rudianto dkk., 2015 )

Kelor dapat tumbuh di dataran rendah sampai di ketinggian 1000 meter di atas permukaan laut (dpl) dan banyak digunakan sebagai pembatas lahan atau pagar di halaman rumah atau ladang bahkan untuk program penghijauan. Perbanyakan tanaman tergolong mudah yakni dengan memperbanyak stek maupun menggunakan biji. Hampir semua dari bagian tanaman kelor bermanfaat dalam kehidupan manusia dan berkhasiat sebagai obat. Tidak hanya itu, Biji kelor merupakan salah satu tanaman yang dapat dipergunakan sebagai salah satu koagulan alami alternatif yang tersedia secara lokal (Rustiah dan Andriani, 2018). Daunnya sering dikonsumsi sebagai sayuran. Selain untuk bahan makanan, daun kelor mengandung fitosterol yang dapat meningkatkan produksi ASI (Air Susu Ibu) bagi wanita yang sedang menyusui dan mengatasi masalah anemia pada anak-anak dan ibu hamil. Ekstrak daun keor mengandung $\mathrm{Fe} 5,49 \mathrm{mg} / 100$ $\mathrm{g}$, sitosterol 1,15\%/100 g, dan stigmasterol 1,52 \% /100 g (Kristina dan Syahid, 2014). 
Hasty Hamzah dkk. / Indo. J. Chem. Res., 2019, 6(2), 88-93

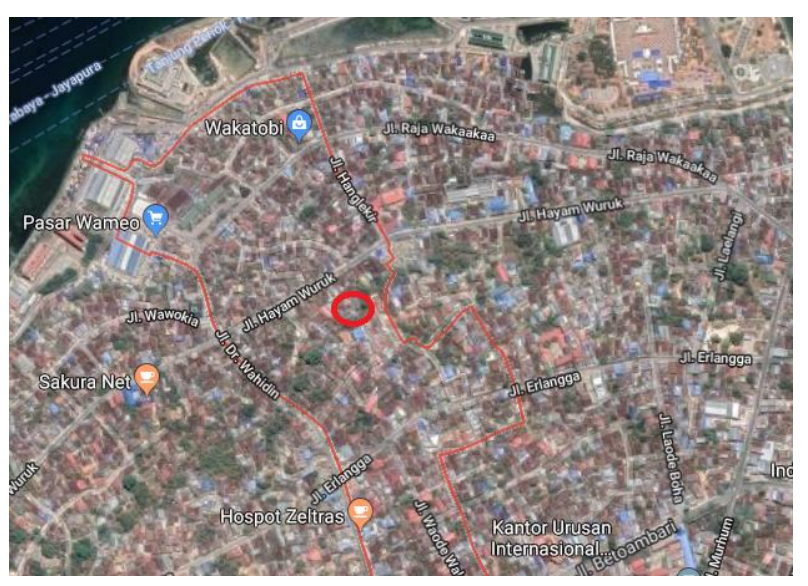

a

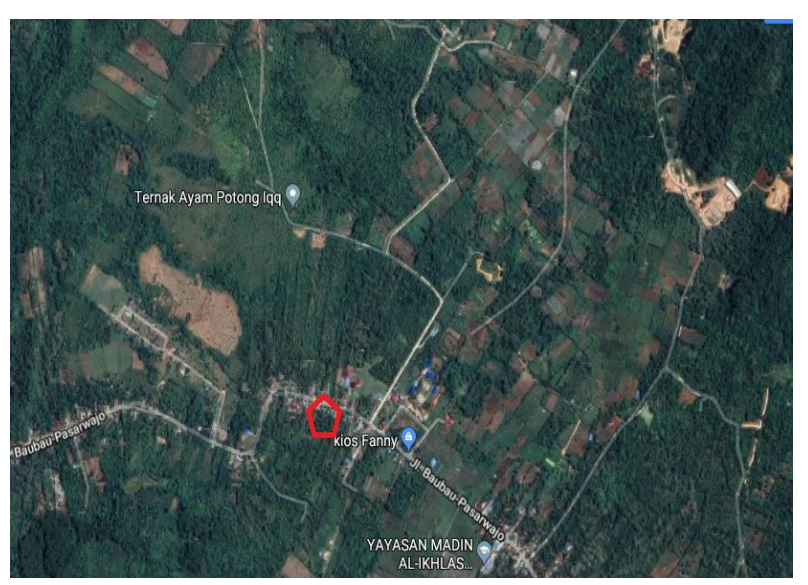

b

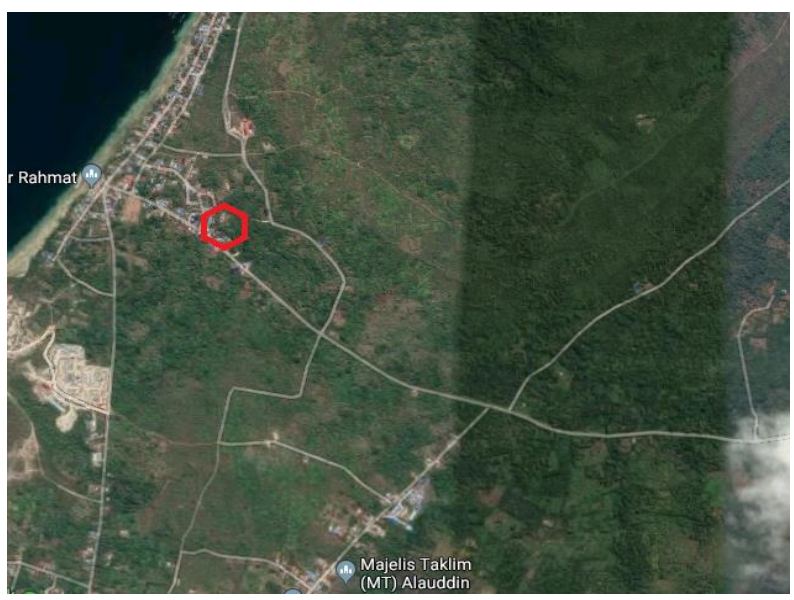

C

Gambar 1. Peta Lokasi penelitian Pengambilan Sampel Daun Kelor (a) Kelurahan Wameo (b) Kelurahan Kaisabu Baru (c) Kelurahan Kantalai

Daun kelor yang kaya akan nutrisi merupakan sumber beta karoten, vitamin $\mathrm{C}$, besi dan potasium. Hasil analisis kandungan Fe dalam daun kelor di Balai penelitian Tanaman Rempah dan Obat pada tahun 2014 menunjukkan hasil yang cukup baik, yaitu dari $1 \mathrm{Kg}$ simplisia dapat menghasilkan kandungan besi sebanyak 54,92 $\mathrm{mg}$ (Balittro, 2014) Zat besi (Fe) adalah mikromineral yang sangat penting dalam tubuh karena berfungsi dalam pembentukan sel darah merah. Zat besi $(\mathrm{Fe})$ dalam pembentukan sel darah merah yakni proses sintesis hemoglobin (Hb) dan dapat pula mengaktifkan beberapa enzim salah satunya yakni enzim pembentuk antibodi. Kekurangan zat besi akan mengakibatkan anemia yang merupakan masalah gizi di Indonesia. Selain itu dapat menurunkan kekebalan tubuh karena berhubungan erat dengan penurunan fungsi enzim pembentuk antibodi (Ramli, 2008)
Kelor selain mudah diperoleh dan tanpa biaya tinggi, mampu membantu pemulihan secara cepat pada anak-anak malnutrisi dibandingkan dengan ibu-ibu yang memberikan nutrisi modern seperti susu bubuk, minyak goreng dan gula. Penelitian di beberapa negara menunjukkan serbuk daun kelor berperan dalam memperbaiki sistem imun. Di India kelor sudah dijadikan tanaman obat (Indian Herbs) sejak puluhan tahun, dan telah dilakukan analisa terhadap kandungan zat-zat bioaktif kelor serta fungsinya. Salah satu dari 49 phytonutrient yang telah dianalisa adalah beta carotene yang berfungsi sebagai phagocitotic activity (Lutfiah, 2012).

Telah banyak riset yang menunjukan bahwa terdapat hubungan antara jumlah kadar zat dengan ketinggian. Sebagaimana penelitian yang dilakukan oleh Fatchurrozak dkk. (2013) yang menguji pengaruh ketinggian tempat terhadap 
kandungan vitamin $\mathrm{C}$ dan zat antioksidan pada buah Carica pubescens di Dataran Tinggi Dieng. Berbagai data dan informasi yang telah disampaikan sebelumnya serta spektrum tumbuh tanaman kelor yang cukup luas maka dipandang perlu untuk melakukan penelitian mengenai analisis kandungan zat besi (Fe) pada daun kelor (Moringa oleifera Lam.) yang tumbuh dengan ketinggian berbeda di Kota Baubau. Berdasarkan latar belakang tersebut maka telah dilakuan studi perbedaan kandungan zat besi (Fe) pada daun kelor (Moringa oleifera Lam.), serta melihat faktor-faktor lingkungan yang mempengaruhi perbedan tersebut.

\section{METODOLOGI}

\section{Bahan}

Bahan-bahan yang digunakan dalam penelitian ini antara lain daun kelor (Moringa oleifera Lam.), aquabides, $\mathrm{HNO}_{3}$ pekat, $\mathrm{HCl}$ pekat, larutan induk besi 1000 ppm dan kertas saring.

\section{Alat}

Alat-alat yang digunakan dalam penelitian ini antara lain adalah SpektroskopiSerapan Atom (SSA), penangas listrik, neraca analitik, oven, tanur listrik, eksikator, labu takar $25 \mathrm{ml}, 50 \mathrm{~mL}$, $100 \mathrm{~mL}$, erlenmeyer $300 \mathrm{~mL}$, pipet volume 25 $\mathrm{mL}$, pipet skala $5 \mathrm{~mL}$, pipet skala $10 \mathrm{~mL}$, pisau, cawan penguap, corong, pipet tetes, batang pengaduk, sendok zat dan botol wadah

\section{Prosedur Kerja \\ Perlakuan Pendahuluan Sampel}

Sampel daun kelor (Moringa oleifera Lam.) pada penelitian ini diambil dari sekitar daerah Baubau dengan metode pengambilan sampel secara acak sederhana. Pengambilan sampel dilakukan di tiga tempat dengan ketinggian berbeda yaitu di Kelurahan Wameo Kecamatan Batupoaro (14 mdpl), Kelurahan Kantalai Kecamatan Lea-lea (58 mdpl) dan Kelurahan Kaisabu Baru Kecamatan Sorawolio (318 mdpl). Berikut adalah peta lokasi pengambilan sampel.

Analisis kandungan zat besi $(\mathrm{Fe})$ daun kelor (Moringa oleifera) dilaksanakan di Laboratorium Forensik Jurusan Biologi FMIPA Universitas Halu Oleo. Sampel daun kelor yang diambil dari ketiga tempat tumbuh yang berbeda terlebih dahulu diberi perlakuan pendahuluan yakni daun kelor dipisahkan dari tangkainya.
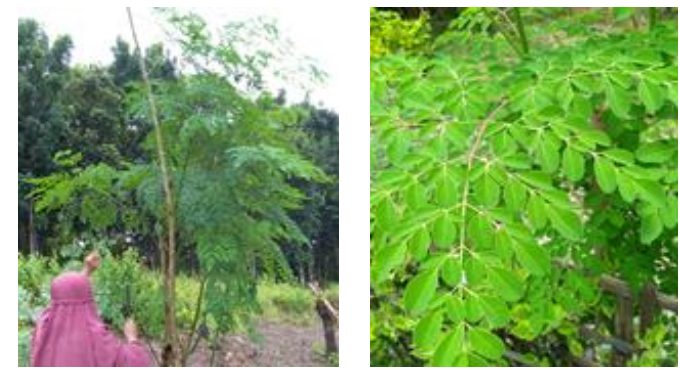

Gambar 2. Pengambilan Sampel Daun Kelor

\section{Analisis Kadar Air}

Analisis kadar air ditentukan dengan cara metode Gravimetri. Objek yang akan dianalisis ditimbang dengan teliti sebanyak 30 gram pada cawan dan dikeringkan pada suhu $105^{\circ} \mathrm{C}$ selama 3 jam kemudian ditimbang hingga bobot konstan.

\section{Preparasi Sampel}

Sebanyak 3 gram sampel kering daun kelor ditimbang dengan teliti dalam cawan penguap dan didekstruksi pada tanur listrik dengan suhu $500^{\circ} \mathrm{C}$ selama 2 jam kemudian didinginkan pada suhu kamar. Abu yang dihasilkan ditambah dengan aquabides sebanyak 10 tetes dan asam nitrat (HNO3) pekat : aquabides (1:1) sebanyak 3 ml. Kelebihan asam nitrat $\left(\mathrm{HNO}_{3}\right)$ diupkan pada lemari asam. Cawan penguap yang berisi sampel dimasukkan dalam tanus listrik dan diabukan selama 1 jam pada suhu $500^{\circ} \mathrm{C}$. Abu didinginkan dan ditambah dengan $5 \mathrm{ml}$ asam klorida $(\mathrm{HCl})$ pekat:aquabides (1:1), kemudian disaring. Filtrat dipindahkan dalam labu takar $25 \mathrm{ml}$ dan cawan dibilas dengan aquabides sebanyak 3 kali kemudian diimpitkan sampai tanda batas.Setelah itu diukur serapan dengan Spektroskopi Serapan Atom (SSA).

\section{Pembuatan Larutan Baku Fe}

Larutan induk besi (Fe) 100 ppm dipipet sebanyak $10 \mathrm{~mL}$ dan dihimpitkan dengan aquabides pada labu takar $100 \mathrm{~mL}$ dengan konsentrasi larutan $10 \mathrm{ppm}$. Selanjutnya larutan baku $10 \mathrm{ppm}$ dipipet sebanyak $1 \mathrm{~mL}, 2 \mathrm{~mL}$, $3 \mathrm{~mL}$ dan $4 \mathrm{~mL}$ dan diimpitkan dengan aquabides dalam labu takar $50 \mathrm{~mL}$ hinga tanda batas. Larutan tersebut berturut-turut $0,2 \mathrm{ppm}$, $0,4 \mathrm{ppm}, 0,6 \mathrm{ppm}, 0,8 \mathrm{ppm}$ dan $1,0 \mathrm{ppm}$. Masing-masing larutan standar $(0,2 \mathrm{ppm}, 0,4$ ppm, 0,6 ppm, 0,8 ppm dan 1,0 ppm) ditentukan 
Hasty Hamzah dkk. / Indo. J. Chem. Res., 2019, 6(2), 88-93

absorbansinya dengan Spektrofotormeter Serapan Atom (SSA).

\section{HASIL DAN PEMBAHASAN}

\section{Analisis Kadar Air pada Sampel Daun Kelor}

Telah dilakukan penelitian untuk menganalisis kandungan zat besi $(\mathrm{Fe})$ berdasarkan perbedaan ketinggian di daerah Kota Baubau. Penelitian diawali dengan penentuan kadar air. Adapun hasil analisis kadar air daun kelor dari berbagai ketinggian dapat dilihat pada Tabel 1.

Tabel 1. Hasil Analisis Kadar Air Pada Daun

\begin{tabular}{|c|c|c|c|c|}
\hline & \multicolumn{2}{|r|}{ Kelor } & \multirow[b]{2}{*}{ Kadar Air } & \multirow[b]{2}{*}{$\begin{array}{c}\text { Rata- } \\
\text { rata }\end{array}$} \\
\hline \multirow{2}{*}{ Lokasi } & \multicolumn{2}{|c|}{ Sampel } & & \\
\hline & & & $(\%)$ & $(\%)$ \\
\hline \multirow{3}{*}{ a } & \multirow{3}{*}{$\begin{array}{c}\text { Ketinggian } \\
14 \text { mdpl }\end{array}$} & Ulangan I & 67,18 & \multirow{3}{*}{69,32} \\
\hline & & Ulangan II & 71,23 & \\
\hline & & Ulangan III & 69,56 & \\
\hline \multirow{3}{*}{$\mathrm{b}$} & \multirow{3}{*}{$\begin{array}{c}\text { Ketinggian } \\
58 \mathrm{mdpl}\end{array}$} & Ulangan I & 71,98 & \multirow{3}{*}{71,92} \\
\hline & & Ulangan II & 72,06 & \\
\hline & & Ulangan III & 71,73 & \\
\hline \multirow{3}{*}{ c } & \multirow{3}{*}{$\begin{array}{c}\text { Ketinggian } \\
318 \text { mdpl }\end{array}$} & Ulangan I & 72,65 & \multirow{3}{*}{72,55} \\
\hline & & Ulangan II & 72,19 & \\
\hline & & Ulangan III & 72,81 & \\
\hline
\end{tabular}

Tabel 2. Data Absorbansi Laruan Standar Fe

\begin{tabular}{cc}
\hline Konsentrasi $(\mathrm{ppm})$ & Absorbansi (A) \\
\hline 0 & 0,0002 \\
0,2 & 0,0052 \\
0,4 & 0,0114 \\
0,6 & 0,0168 \\
0,8 & 0,0219 \\
1 & 0,0275 \\
\hline
\end{tabular}

Pada penelitian ini, kadar air pada daun kelor dianalisis dengan metode Gravimetri. Kadar air lebih tinggi diperoleh pada ketinggian 318 mdpl (dataran tinggi) yakni 72,55\%. Hal ini disebabkan karena iklim di daerah ketinggian, dimana intensitas matahari kurang, suhu udara rendah dan kelembaban udara tinggi. Menurut Tarmedi (2006), semakin tinggi tempat maka suhu semakin rendah dan kelembaban tinggi. Pada kondisi kelembaban yang tinggi menandakan kandungan air juga cukup tinggi dan selanjutnya akan mempengaruhi kadar mineral lainnya.

\section{Analisis Kadar Zat Besi (Fe) pada Sampel Daun Kelor}

Hasil pengukuran serapan larutan sampel daun kelor untuk analisis zat besi $(\mathrm{Fe})$ dengan Spektroskopi Serapan Atom (SSA), diperoleh hasil konsentrasi zat besi $(\mathrm{Fe})$ pada daun kelor yang tumbuh di berbagai ketinggian ditampilkan pada Tabel 3.

Tabel 3. Hasil Analisis Kadar Besi (Fe) Pada Daun Kelor

\begin{tabular}{ccccc}
\hline Lokasi & Sampel & $\begin{array}{c}\text { Kadar zat } \\
\text { besi (Fe) } \\
(\mathrm{mg} / 100 \mathrm{~g})\end{array}$ & $\begin{array}{c}\text { Rata- } \\
\text { rata }\end{array}$ \\
\hline \multirow{2}{*}{ a } & Ketinggian & Ulangan II & 6,31 & $\mathbf{6 , 2 8}$ \\
& 14 mdpl & Ulangan III & 6,24 & \\
b & Ketinggian & Ulangan II & 5,69 & $\mathbf{5 , 6 1}$ \\
& 58 mdpl & Ulangan III & 5,55 & \\
& Ketinggian & Ulangan I & 3,76 & \\
c & 318 mdpl & Ulangan II & 3,94 & $\mathbf{3 , 8 6}$ \\
& & Ulangan III & 3,87 & \\
\hline
\end{tabular}

Pada Tabel 3 dapat dilihat hasil pengukuran kadar zat besi $(\mathrm{Fe})$ pada daun kelor yang tertinggi yaitu daun kelor yang diambil di daerah Kelurahan Wameo atau berada di dataran rendah 14 mdpl yakni 6,28 mg dalam 100 gram sampel daun kelor. Hasil penelitian yang serupa dilakukan Nurahma dkk. (2010) di Desa Matajang Kabupaten Bone memperoleh hasil kadar zat besi (Fe) pada daun kelor di daerah tersebut tertinggi 6,22 mg dalam $100 \mathrm{mg}$ sampel daun kelor. Berkurangnya ketinggian, intensitas sinar matahari dan temperatur semakin tinggi. Hal ini dikarenakan pada daun terjadi proses fotosintesis yang melibatkan zat besi $(\mathrm{Fe})$ sebagai pembawa electron pada fase terang fotosintesis. Zat besi (Fe) sangat penting dalam pembentukan klorofil, namun tidak menjadi bagian dari molekul klorofil tersebut. Dengan demikian, zat besi $(\mathrm{Fe})$ lebih banyak terdeposit pada daun. Artinya semakin tinggi intensitas matahari akan mempermudah berlangsungnya proses fotosintesis dan zat besi (Fe) lebih besar terdeposit. Besi bersifat esensial sebab besi (Fe) merupakan zat pembawa electron dalam fotosintesis dan respirasi. Selain itu pula sifat dan tekstur tanah di sekitar pengambilan sampel merupakan tanah yang mengandung zat oganik 
yang kaya akan hara tanaman berupa makro nutrien.

Pengaruh ketinggian terhadap kadar zat dalam daun kelor, juga telah diteliti oleh Cahyati dkk. (2016) yang meneliti pengaruh kadar asam askorbat daun kelor berdasarkan ketinggian. Dalam penelitiannya diperoleh kandungan kadar asam askorbat pada daun kelor lebih tinggi pada dataran rendah (pesisir) dibandingkan dengan daerah pegunungan (dataran rendah). Yulianti dkk. (2017) juga telah melakukan penelitian analisis kadar $\beta$-karoten dalam ekstrak petroleum eter daun kelor dari daerah pesisir dan pengunungan, hasil penelitian diperoleh bahwa daun kelor daerah pesisir memiliki aktivitas antioksidan lebih tinggi dibandingkan daerah pengunungan.

Hasil penelitian pada Tabel 2, menunjukan rendahnya kadar Fe pada ketinggian 318 mdpl (dataran tinggi) di Kelurahan Kaisabu. Hal ini dapat disebabkan oleh beberapa hal, yaitu adanya perbedaan kadar mineral pada tanah tempat tumbuh, derajat keasaman tanah $(\mathrm{pH})$ dan tekstur tanah. Tekstur tanah dari dataran tinggi (318 mdpl) di Kelurahan Kaisabu mengandung kapur dengan derajat keasamaan $(\mathrm{pH})$ sedikit asam yakni 6. Adanya zat kapur yang berlebihan akan mengurangi ketersediaan zat besi (Fe). Kationkation logam akan menyusutkan serapan besi (Fe) pada tanaman. Hal ini dikarenakan kationkation tersebut bersaing dengan besi $(\mathrm{Fe})$ selama tahapan penyerapan hara, sehingga mengurangi serapan besi $(\mathrm{Fe})$. Lebih lanjut menurut Tarmedi (2006), semakin tinggi tempat maka suhu semakin rendah dan kelembaban tinggi. Pada kondisi kelembaban yang tinggi menandakan kandungan air tinggi, akibatnya unsur hara akan semakin rendah karena proses pencucian pada lahan tersebut. Pada kondisi seperti ini, beberapa vegetasi akan mengalami kesulitan dalam proses pencucian pada lahan tersebut.

Pengaruh umur tanaman dapat dilihat dari hasil penelitian ini, bahwa daun kelor di dataran rendah (Kelurahan Wameo) yang memiliki kadar zat besi $(\mathrm{Fe})$ lebih tinggi dibandingkan dataran sedang (Kelurahan Kantalai) dan dataran tinggi (Kelurahan Kaisabu) karena tanaman kelor yang berumur lebih tua dibandingkan kedua tempat lainnya. Ismail (dikutip dalam Nurrahma dkk., 2010) menyatakan bahwa adanya perbedaan penyerapan mineral tanaman yang berumur lebih tua dengan tanaman yang berumur lebih muda disebabkan karena tanaman berumur lebih muda berkonsetrasi untuk pertumbuhannya yakni meninggikan batang dan lebih memperkuat perakarannya. Sedangkan, tanaman yang berumur lebih tua berkonsentrasi pada penyerapan mineral dimana dengan sistem perakaran yang sudah besar menyerap mineral dan zat organik lebih banyak yang dibutuhkan oleh tubuh tumbuhan pada proses metabolismenya.

\section{KESIMPULAN}

Dari penelitian ini dapat disimpulkan sebagai bahwa ada perbedaan jumlah kandungan zatbesi (Fe) daunkelor (Moringa oleifera Lam.) di berbagai ketinggian tempat tumbuh. Diperoleh kadar besi (Fe) dataran rendah $14 \mathrm{mdpl}$ (KelurahanWameo) adalah 6,28 mg per $100 \mathrm{~g}$ sampel daun kelor, dataransedang $58 \mathrm{mdpl}$ (Kelurahan Lea-lea) adalah 5,57 mg per $100 \mathrm{~g}$ sampel sedangkan di dataran tinggi $318 \mathrm{mdpl}$ (Kelurahan Kaisabu) adalah 3,86 mg per $100 \mathrm{~g}$ sampel. Faktor yang mempengaruhi jumlah kandungan zat besi pada daun kelor yaitu ketinggian yang lebih lanjut mempengaruhi intensitas cahaya matahari, kelembaban udara. Faktor lain dapat disebabkan oleh kondisi tanah (tekstur, kelembaban, nutrient dan $\mathrm{pH}$ ).

\section{DAFTAR PUSTAKA}

Cahyati, R.D., Natsir H, Wahab, A.B., 2016, Analisis Kadar Asam Askorbat Dalam Ekstrak Daun Kelor (Moringa oleifera Lam.) Dari Daerah Pesisir dan Pegunungan dan Potensinya Sebagai Antioksidan, Skripsi, Jurusan Kimia FMIPA UH. Makassar.

Fatchurrozak, Suranto, Sugiyarto, 2013, Pengaruh Ketinggian Tempat Terhadap Kandungan Vitamin C dan Zat Antioksidan Pada Buah Carica pubescens di Dataran Tinggi Dieng, El-Vivo, 1 (1): 24-31.

Kristina N., Syahid S., 2014, Pemanfaatan Tanaman Kelor (Moringa oleifera) Untuk Peningkatan Produksi Air Susu Ibu, Warta Penelitian dan Pengembangan Tanaman Industri, 20 (3), 26-29.

Lutfia, F., 2012, Potensi Gizi Daun Kelor (Moringa oleifera) Nusa Tenggara Barat, Media Bina Ilmiah, 6 (2), 42-50. 
Hasty Hamzah dkk. / Indo. J. Chem. Res., 2019, 6(2), 88-93

Nurrahma, A., Alimin, Rustia, W.A., 2010, Analisis Kandungan Zat Besi (Fe) pada Buah Kelor dan Daun Kelor (Moringa oleifera) yang Tumbuah di Desa Matajang Kec.Dua Boccoe Kab.Bone, Alkimia, 1(1), $10-11$.

Ramli, 2007, Analisis Kadar Kalsium (Ca) dan Besi (Fe) pada Bawang Merah Yang Beredar di Pasaran Secara Spektrofotometer Serapan Atom, Skripsi, FMIPA UNM Makassar.

Rudianto, 2015, Studi Pembuatan Analisis Zat Gizi Pada Produk Biskuit Moringa Oleifera Dengan Subtitusi Tepung daun Kelor, Skripsi, Program Studi Ilmu Gizi FKM UH, Makassar.

Rustiah, W., Andriani, Y., 2018, Analisis Serbuk Biji Kelor (Moringa Oleifera, Lamk) Dalam Menurunkan Kadar COD Dan BOD Pada Air Limbah Jasa Laundry, Indo. J. Chem. Res., 5(2), 508-512.
Tarmedi, 2006, Keanekaragaman Cendawan Mikoriza Arbuskula di Hutan Sub Pegunungan Kanojang Jawa Barat, Skripsi, Institut Pertanian Bogor, Bogor.

Tjitrosoepomo G., 2013, Taksonomi Tumbuhan (Spermatophyta), Gadjah Mada University Press, Yogyakarta,

Winarti S., 2010, Makanan Fungsional. Graha Ilmu, Yogyakarta.

Yulianti, Natsir, H., Wahab, A.W., 2017, Analisis Kadar $\beta$-Karoten Dalam Ekstrak Petroleum Eter Daun Kelor (Moringa oleifera Lam.) Dari Daerah Pesisir dan Pegunungan Serta Potensinya Sebagai Antioksidan, Skripsi, Jurusan Kimia FMIPA UH, Makassar. 